\title{
Feasting with Buddhist Women: Food Literacy in Religious Belonging
}

\author{
Paulina Kolata | ORCID 0000-0003-0051-4389 \\ Centre for East and South-East Asian Studies, \\ Lund University, Lund, Sweden \\ paulina.kolata@ace.lu.se \\ Gwendolyn Gillson | ORCID 0000-0002-5381-7191 \\ Department of History, Philosophy, Political Science, \\ and Religion, Illinois College, Jacksonville, IL, USA \\ gwendolyn.gillson@ic.edu
}

\begin{abstract}
This ethnographic study shows that women's knowledge and practices involving food in Japanese Buddhist contexts circulate as gendered currency. It emphasizes how what we term "food literacy" cultivates aesthetic and affective senses of belonging among Buddhist practitioners. We argue that this embodied knowledge helps women negotiate their experiences of Buddhism and show how these experiences articulate the complexities of their bounded and self-disciplining Buddhist selves. Women use food literacy to teach, learn, and practice the way Buddhism feels and etch it into their own and others' emotional, social, and material bodies. By recognizing women as stewards of religion, particularly through food literacy, we also elucidate how women's uses of mundane practices illuminate food literacy as a value carrier that generates belonging through food. Such practices can equally become sites of failure to connect if the intended recipients do not share understandings or appreciations of the aesthetic and affective dimensions of it.
\end{abstract}

\section{Keywords}

Buddhist women - Japanese Buddhism - food literacy - religious belonging - affect gendered currency 
In June 2017, members of Myōkōji, ${ }^{1}$ a midsize True Pure Land temple in rural Hiroshima Prefecture, visited Kyoto for their annual trip to the grave of the founder of their Buddhist sect. Following the mausoleum visit, Suzuki Aki, ${ }^{2}$ the wife of the temple's head priest, organized a meal intended as an enjoyable culmination of the memorial rites. She selected one of Kyoto's expensive multicourse restaurants famed for shöjin ryōri, a devotional type of Buddhist vegetarian cuisine prepared according to monastic dietary rules, which in True Pure Land teachings symbolizes restraint and austerity. Despite its modest roots and emphasis on simplicity in presentation and flavor, it is extremely elaborate when served in a commercial setting. Before the trip, Aki spent a week researching shōjin ryōri establishments and skillfully negotiated down the price of this shared culinary experience. She felt her job was to ensure the bodily nourishment of her parishioners accompanied the spiritual one at the mausoleum. During a two-hour meal, various beautifully presented dishes arrived at regular intervals, starting with creamy sesame tofu, a delicate mushroom broth garnished with mizuna stems, and fried bundles of paperthin tofu skin filled with nameko mushrooms and shiso leaves. All met the first few dishes with excitement. However, as time passed, most elderly members began developing leg cramps from sitting at the low table and their enthusiasm started to wear off. Flanked by two female members, Aki patiently listened to their discussion on how most of the ingredients used in the served dishes could have been sourced for free in the mountains in their own backyards in Hiroshima. By the time a perfect sphere of seafoam shiso sorbet arrived for dessert, the conversation at the table had shifted toward the outing's unnecessary extravagance. Although the women and men gathered enjoyed the look, taste, smell, and finesse of the cookery presented, they were concerned about the food's affordability for members of a rural temple like Myōkōji. Aki was disappointed that her effort to provide this experience felt excessive.

In a similar setting a few months prior, the International Ladies Association of Buddhism (ILAB, an urban nonsectarian lay organization for women interested in Buddhism) was on a spring outing to Chieji, a Rinzai Zen Buddhist temple located in Kamakura, approximately two hours south of Tokyo. As the culmination of their hours-long visit, the participants sat down at the restaurant attached to Chieji to also enjoy a shōjin ryōri feast. In the Zen context, the exquisitely beautiful food, lightly seasoned with soy sauce, is meant to represent spiritual purity but women appreciated its aesthetic elegance and

1 All names of people and temples have been changed to protect privacy.

2 We follow Japanese naming conventions, giving surnames first. 
culinary precision. The mountain potato soup stretched like melted cheese as the elderly husband of longtime ILAB member Watanabe Ayako grinned, pulled it up with his chopsticks, and reminisced about eating it as a child. When the dessert arrived, Hashimoto Junko, an energetic elderly Catholic woman with an interest in Buddhism, puzzled over how to eat it: two meticulously perfect rectangular boxes made of a cake-cone-like substance that revealed red bean paste upon pulling off the lids. As a Catholic, she was unfamiliar with this Buddhist cuisine's etiquette and so surreptitiously watched other tables to learn. Watanabe quickly realized Hashimoto's distress and turned to help, telling Hashimoto to replace the lid and cut it delicately with chopsticks. Watanabe's husband deferred to his wife's expertise, nodding along as she demonstrated, perhaps as a reflection of the instruction he received at her hands earlier, allowing him now to eat his dessert with precision. Despite her tutelage, Hashimoto's sweets cracked and crumbled all over her plate. Once the plates had been cleared away, the participants followed their meal with a Buddhist prayer, with over thirty voices, primarily of women, rising to envelop the raised dais where they sat, flowing out through the thin curtains into the restaurant beyond to bless the other diners' food.

These carefully crafted Buddhist feasts reveal how knowledge and practices concerning food, and their associated aesthetics, understood as sensorial processes of meaning-and-value-making, can generate senses of belonging and articulate its boundaries. For Myōkōji members, the food was appreciated but seen as an extravagance, unnecessary to their overall pilgrimage, even as it was carefully orchestrated by Aki as a valuable Buddhist experience. Conversely, ILAB members appreciated the food and atmosphere, which presented a problem for non-Buddhist Hashimoto who did not understand how to eat her food in the proper Buddhist fashion. With the help of Watanabe, however, she learned how to enjoy her food correctly, pulling her more closely into Watanabe's Buddhist universe. Women in both instances attempted to negotiate particular senses of Buddhist belonging by drawing on knowledge and practices surrounding food. We term this fluency as "food literacy." They crafted these senses of belonging by activating their food literacy as a form of currency to circulate and generate value which is gendered and gendering. The aesthetics of such actions are rooted in the quotidian practices of everyday life involving circulation, boundary making, and continuous processes of negotiation and (self-)disciplining. Drawing on two different Buddhist contexts, we argue that women deploy the gendered currency of food literacy and draw on its aesthetic capacities to generate religious belonging. 
Our material comes from two separate periods of ethnographic fieldwork: with True Pure Land temple communities in Hiroshima Prefecture in 20162017, and with ILAB in Tokyo in 2017. The examples from Hiroshima Prefecture present stories of women enmeshed in the day-to-day realities of rural Buddhist temple communities. The protagonists of these stories are temple wives and lay Buddhist women who are often members of Buddhist women's groups affiliated with local temples. The ILAB context focuses on a nonsectarian collective of Buddhist nuns, female priests, leaders of lay branches of larger sects, lay practitioners, and women interested in learning about Buddhism, drawn primarily from urban Japan and the global Buddhist community.

\section{1 \\ The Aesthetic Capacities of Food Literacy}

Similar to other religious contexts (Trzebiatowska and Bruce 2012: 124-146; Pérez 2016), in Buddhism, women control and organize food as religious practice (McDowell 2000; Starling 2019), mirroring their dominance within domestic labor more generally. In the opening vignettes, women deploy food literacy to create Buddhist belonging by inspiring and articulating Buddhist morality. In the Mahayana tradition, one way of doing Buddhism is through cultivating bodhisattva virtues. ${ }^{3}$ Following a bodhisattva path, however, is notably gendered: women can follow it by practicing womanly morality, speech, behavior, and labor (Meeker 2019; Li 202O). Domestic space, of which food is part, is a sphere where women can express their Buddhist identities by practicing those virtues. Jessica Starling (2019) shows that women in Japanese Buddhist contexts are experts in domestic religious labor interwoven with broader social constructions of gender and gender roles in Japanese society. Women use literacy in the domestic sphere, specifically food literacy, to realize Buddhist moralities in their everyday lives. Part of that daily practice is to teach about Buddhism and thus inspire and nurture Buddhist virtues in others.

Food literacy, we therefore argue, relates to any kind of embodied knowledge and practices regarding food and its affective potential: how to cook, present, provide, and appreciate it. Women's food literacy in the Buddhist context is circulated as gendered currency that brings about aesthetic and affective connectivity among Buddhist practitioners. It becomes a currency insofar as it

3 A bodhisattva is a being on the path toward buddhahood and leads others toward enlightenment. The bodhisattva path involves perfecting six virtues including giving (dāna) and morality (śila). 
flows from person to person, socializing them into that literacy and enabling the preservation and circulation of knowledge and the value encoded in it. This currency is thus not transactional. Although a nontransactional understanding of currency might appear radical, it draws on the etymological meaning of the term: interpersonal circulation and continuity of public knowledge. ${ }^{4}$ Therefore, we interpret currency as a carrier of shared values and a vehicle for fostering belonging that constitutes an alternative to exchange-driven capitalist economic relations (Hart 2000; Gunson 2019). The notion of value we evoke is processual (Munn 1986; Graeber 2001) and acquired in the contexts of relationships (Bender and Taves 2012: 10). As such, by deploying the currency of food literacy, women make Buddhism perceptible in this world. Food literacy is thus necessarily relational and fluid. It carries and produces value used to curate and envision belonging, which augments that value as it circulates among people. Food literacy itself draws on aesthetic, affective, and emotional knowledge and actions concerning the preparation, presentation, and consumption of food as a religious practice. Women, such as Aki and Watanabe introduced above, cultivate and employ their literacy as an essential part of doing Buddhism, nurturing others through food that physically and emotionally sustains their belonging. As a currency, food literacy circulates between and among women to create deep affinities to various Buddhist communities that recognize and appreciate their gustatory values and religious expertise.

In the opening vignettes, women orchestrated or ushered others through that experience. Watanabe, drawing on her Buddhist food literacy, guided Hashimoto toward her own understanding of what it means to embody Buddhist virtues through food and its consumption. Her expertise in this area was equally recognized by her husband, for whom food constituted a realm where gendered modalities of belonging were cultivated and mutually acknowledged. Likewise, Aki coordinated a shōjin ryōri feast to enhance the trip's Buddhist meaning. The participating men and women recognized the Buddhist dimensions of their experience and her expertise in crafting it. Yet there was a mismatch between the restaurant's and the members' interpretation of the virtue of simplicity. Surprisingly, Aki's efforts resulted in creating a feeling of togetherness through a debate that ensued concerning the perceived

4 The term "currency," from the Latin currens or currere meaning "to run," did not acquire the modern meaning as a medium of exchange until 1729 (Onions 1966: 237). Economic anthropologists such as Kevin Hart $(2000,2010)$ have challenged this monetary understanding of currency and pushed against its prevalent exchange-driven interpretation. Exchange models often see food as instrumental, particularly when drawing on Maussian models of ritual giftgiving (Befu 1968). 
lack of frugality and simplicity in the shōjin food served to the group. Thus, Watanabe and Aki used their food literacy to create senses of Buddhist belonging that, notably, did not always work as intended. Nonetheless, Myōkōji's members' reactions are further examples of food literacy that, similarly to Watanabe's husband, attest to its relational nature. Food literacy is also intrinsically gendered insofar as it corresponds with responsibilities women share due to their gender, rather than their social position or occupation.

By mobilizing concepts of currency, value, gender, and belonging, we argue that women's food literacy engenders connections to, within, and through Buddhism. We draw on Lucy Long's (2004) conceptualization of "foodways" as processes involved in the production, preservation, presentation, and consumption of food. In particular, we focus on the everyday practices women employ in their Buddhist lives in order to cultivate senses of religious belonging. Elizabeth Pérez argues that women's religious practices surrounding food can best be understood through the concept of "micropractices," which are "routine and intimate sequences of operations that can be broken down into more minute units of activity.... Despite their modest scale and narrow limits, micropractices sustain religious formations by naturalizing the conventions that govern particular communities" and bring people into particular religious worlds (Pérez 2016: 9-10). Women in Pérez's work use micropractices to create desired religious senses that reveal how the production of food for the spirits and themselves cultivates "feelings" of religious practice through their bodies (6). Similarly, social and ritual nurturing of interrelations between humans and nonhuman entities in the Buddhist context often, if not always, revolve around food and foodways controlled and organized by women, be it through communal feasting or devotional practices of material and emotional labor.

Through our ethnography, we follow Pérez's focus on micro-level practices, but push beyond sensorial forms to address the literacy that underpins them. We are thus not only interested in the sensuous interactions of the body with food, but more acutely the knowledge and embodied and affective uses of food. This expertise, that we see as gendered and ever circulating, is deployed to reveal the affective connections it strives to maintain and is cultivated through women's micropractices over time. It is an unending process of mastery that circulates and accumulates value to generate traction within Buddhist communities. When traction sticks, belonging works. As such, food literacy engages particular affects and aesthetics that attempt to generate and nurture Buddhist identities. These "aesthetic formations" are not, as Birgit Meyer (2009) suggests, "fixed," but rather rooted in micropractices and knowledge of doing Buddhism surrounding the most quotidian of practices: the creation and consumption of food. 


\section{$2 \quad$ Gendered Currency in Circulation}

For members of most Buddhist women's associations, it is customary to be asked to take turns in providing freshly cooked meals for the local temple head priest during his wife's absence. Yamamoto Masako, an eighty-two-year-old member of Myōkōji's neighboring temple in rural Hiroshima, told Kolata that food preparation was a crucial form of Buddhist practice for supporting her local temple:

Yamamoto: It is not much different than offering food or money to the temple. But rather than offering raw ingredients for the head priest's wife to cook, I do the cooking. You are usually asked to do it, if people know that you are good at it.

Kolata: So it depends on your cooking skills? It requires some additional expense and time though, right?

Yamamoto: Well, you need to be good at it, but extra time? Not really. I just prepare an additional portion of what I make at home for my family, but ensure it's my signature stuff. This way, I can support the priest's wife and feed some tasty food to the buddhas.

Kolata: What do you mean? I thought you were feeding the head priest.

Yamamoto: Our head priest looks after the temple. Feeding him gives his body strength to focus on his part of the job. Who knows what he would eat otherwise? ... It makes me think more about the food I prepare. I focus on the purpose and work harder to make it taste and look good. In the summer, I use fresh ingredients from my garden. In the autumn, I might go foraging for plants and mushrooms and use local natural ingredients ... It is simple stuff but done well. It must feel right.

For Yamamoto, providing sustenance to her local priest is a form of Buddhist practice, a recognition of her food literacy, and an opportunity to materialize it. In preparing the food, she can deploy her knowledge of local environments and utilize her cooking skills to produce food that is intentional and enjoyable through simplicity and quality of flavors. One of her signature offering sets was creamy pumpkin soup and onigiri rice balls stuffed with shiitake mushrooms mixed with shiso leaves and sesame accompanied by plum jelly for dessert. Most of her ingredients came from her rice paddy, garden, and the forest 
covering the hill behind her house. So it is not only the skill and intentionality applied in preparing the food that is notable. She also perceived it as an expression of Buddhist generosity, one of the virtues of the bodhisattva path. Dāna, an act of giving, is an inherent element of Buddhist practice that defines lay practitioners' relationship with their local temple and temple family. ${ }^{5}$ Offering food is a meritorious act practiced by women and men alike to accumulate good karma, express gratitude, and maintain temple-parishioner relations. However, the labor and embodied knowledge involved in the preparation of food is usually women's purview. As such, women like Yamamoto draw on their food literacy to foster connections between themselves, Buddhist temple families, and the buddhas.

Yamamoto's and others' food literacy therefore transforms the personal into the universal and vice versa. As a currency, it has the "ability to sustain local meaning and universal connections at the same time" (Hart 2000: 160). Keith Hart (2000) conceives of currency as a "memory bank," a tool for forging connections and envisioning community and a vehicle for learning to manage relations with others. By providing cooked meals for her local priest, Yamamoto deployed her food literacy in precisely these ways. She practiced Buddhist generosity and, as a fellow Buddhist woman, supported the head priest's wife in her domestic labor. Her expertise with food thus constitutes value that is created, sustained, and circulated through particularly gendered means to enable the cultivation of karmic connections, as well as authority and power outside or alongside more traditional systems of religious hierarchy. Women are therefore custodians of sustaining the continuity of both private and public knowledge of food in Buddhist contexts, combining their literacy in the domestic sphere with their subjective understanding of the Buddhist teachings in order to etch the aesthetic feeling of Buddhism in people's embodied memory. As Yamamoto explained, the way women do Buddhism with food literacy has to "feel" right. Thus, how women create, serve, and consume food constitutes part of the aesthetic framework of their Buddhist practice. These practices also nurture people's karmic connections generated and curated at the micro-level through the emotional and material dimensions of quotidian practice owing to the literacy and expertise of women like Yamamoto.

Food's aesthetic dimensions that food literacy allows women to create and circulate is also of importance for Yamamoto. Food is relational and is meant

5 Dāna connotes the virtue of generosity, charity, or almsgiving, and refers to the Buddhist practice of giving. In Japanese contexts it relates to the term danka, which denotes mutually dependent temple - parishioner relationships (see Covell 2005; Williams 2005: 13-37). For broader literature on Buddhist gifts, see: Caple 2015; Sihlè 2015 . 
to "feel right" and evoke the same experience in those receiving it. Through feeding others, including the buddhas, she generates and maintains networks where emotions delineate the boundaries between the individual and social and is thus an example of where "affective value shapes the surfaces of bodies and worlds" (Ahmed 2015: 10). ${ }^{6}$ By sourcing natural quality ingredients and preparing her signature plum jelly, Yamamoto imbues these foods with affective value. Her commitment and generosity shared through her food and skill aligns her own Buddhist identity with broader ideals of Buddhist virtues and helps to actively form a Buddhist community within specific mutually appreciated values. Food literacy is therefore an example of gendered currency precisely because of the entanglement of the material and emotional dimensions encoded within food as a medium for effecting a sense of religious belonging (Gross 2019, 2021), whereby people not only continuously (re)learn but (re)remember how to belong in Buddhist environments. Orchestrating food experiences is meant to bring individuals into Buddhist communities and to foster belonging through a circulation and appreciation of shared embodied memories of Buddhism. Doing so materializes women's Buddhist values in a way that also strives to enable the processes of cultivating others' Buddhist selves. Employing food literacy is also then effectively a reminder to the temple custodians of their duties and the values they are meant to embody and, in turn, inspire in others.

In contrast, Myōkōji's head priest and his wife (Aki) featured in the introduction were a slight anomaly when it comes to relying on local women's culinary labor during Aki's absences. Her husband cooked and the pair often prepared family meals together. Aoyama Ayako, one of the female members, complained to Kolata, "I suppose it is good that our head priest cooks. Things are supposed to be a little more equal now [between men and women], but cooking is one way we [women] can support the temple." When Kolata asked why it was important to her, she explained that growing and donating crops to the temple was labor she shared with her husband. However, she felt that lay practitioners' labor at the temple was meant to be gendered: men tend to temple repairs and other "dirty jobs" while women "feed the buddhas." She remarked, "That's our job. Equality or not." The very subjective capacity for doing Buddhism through food literacy afforded to Yamamoto was not available to Aoyama who felt that her opportunities for currency circulation were being limited. She neither was able to partake in the generosity of feeding the buddhas and supporting the temple custodians, nor to deploy her food literacy as

6 See Kolata 2019 on labor as generative of karmic, emotional, and material connections in Japanese Buddhism. 
an act of womanly solidarity. The head priest thus unknowingly deprived her of the currency that was supposed to be gendered and, as such, borrowed her means of belonging. The gender equality in Myōkōji's family kitchen distorted the dynamics of traditional foodways and how some local women felt they could strengthen their Buddhist connections through food expertise. A challenge to Aoyama's sense of belonging as a Buddhist woman is a challenge to the traditional values she memorized as the foundations of socioreligious morality and to her ability to make Buddhism with food. ${ }^{7}$ Aoyama generates her sense of belonging, practically and aesthetically, not simply by possessing that food literacy but also by her choice and ability to embody it through practice. She became effectively unable to circulate this currency as a means for transforming her personal connections into a more universal project of sustaining a local Buddhist community. At Myōkōji, social transformations in domestic labor roles inspired by second- and third-wave feminist values such as gender equality (Kawahashi 2003; Salgado 2013: 21-48) clashed with Aoyama's ideal of Buddhist women's and men's roles (see Caple 2021 [this issue]).

Gillson's encounter with Sakurai Fusae, a female Buddhist head priest and ILAB board member, illustrates that women can also rely on food literacy as an articulation of their Buddhist identities in addition to their authority as Buddhist professionals. Sakurai hosted the January and June Buddhist Cultural Exchange Circles in 2017 at her small Pure Land temple in Tokyo. After sutra chanting, walking recitations, and painting pictures of Amida Buddha, ${ }^{8}$ participants were invited for conversation over food and drinks, including a selection of tea bags and elegant store-bought sweets like fluffy Japanese cheesecake, chocolate cream cake, and citrus layer cake. These purchased sweets supplemented a red bean-paste sauce at the January meeting prepared by Sakurai and almond pudding at the June meeting prepared by a Taiwanese nun. Sakurai announced both desserts' homemade quality at each meeting and encouraged the participants to try everything, but especially the homemade sweets.

Sakurai differs from laywomen in Hiroshima in that she is an ordained Buddhist priest. However, she utilizes and in fact emphasizes the place of food within her temple at the ILAB meeting, which helps illustrate her belonging as two-fold: first as a Buddhist ritual and scriptural specialist within the Buddhist

7 Jessica Starling reports similar tensions and negotiations of labor in the kitchen being divided along gendered lines, where presence of a male Buddhist priest in the kitchen is seen as an intrusion (Starling 2019: $57-58$ ).

8 Amida is the primary buddha within Pure Land Buddhism. Painting Amida Buddha, alongside sutra chanting and recitation, are widely practiced merit-making activities (Lowe 2017). 
institutional community, and second as a Buddhist woman drawing on her food literacy to forge connections with other Buddhist women. Every ILAB host, regardless of location or featured activities, concludes gatherings with the consumption of food and its associated expectation of enjoyment. Sakurai is no exception. She recognizes the role that the circulation of culinary affects plays in forging connections, as well as in collecting and triggering gustatory memories.

Concurrently, she helps illustrate the issues Aoyama encountered in the previous vignette. With her own well-kept temple, priestly robes, and neatly coiffed short hair, she displayed belonging to the Buddhist establishment. Nevertheless, she still felt it necessary to orchestrate and serve carefully crafted, if not opulent, food for her Buddhist guests. Despite priestly credentials, she still assumed her socially expected role as an expert host, highlighting how women utilize their food literacy to stage encounters that cultivate Buddhist belonging. Sakurai shows how gendered currency can occur alongside other forms of belonging and how the value of that currency can vary depending on the situation. Her food is not as lavish as that prepared by women at some other local temples, in part because she is an ordained priest, yet she employs her food literacy by attending closely to the aesthetics of food through beautiful cakes supplemented by homemade traditional sweets. The gendered currency she draws on is contextual and fluctuates depending on other factors at play in the cultivation of Buddhist ties.

Buddhist women thus utilize food literacy to create, transform, and sustain their Buddhist worlds, relying on aesthetic practices and knowledge concerning food as a source of religious sustenance. Food as a material thing holds a notable place among things through which religion happens (Arnold 2000; Banerji 2006; Zeller 2017), insofar as it is a natural substance necessary for nurturing the human body that requires constant contact, creation, and production. However, for our interlocutors, it is food literacy that possesses intangible dimensions that facilitate nourishment of the social and emotional body. It partly works through memory, ${ }^{9}$ bringing women together in the present by tying themselves simultaneously to a local and broader Buddhist past that utilized what they perceive as the same Buddhist values and expertise. Food literacy therefore constitutes gendered currency because food must be consumed on the individual level, is often produced at the local level for and by Buddhist practitioners, and is prepared and consumed as part of larger interrelational processes crafting belonging. Drawing on their domestic and Buddhist expertise around food, women create affective boundaries of belonging within

9 For an overview of the discussion on food and memory, see Holtzman 2006. 
existing religious structures. This brings the largely individual act of physically preparing and consuming food into the broader relational and bounded foodway processes in which women are embedded as Buddhist active agents.

One morning in August 2016, Kolata joined members of Myōkōji's Buddhist women association (fujinkai) in the temple kitchen, affectionately referred to as the "fujinkai kitchen," to prepare a meal for fellow parishioners and the guest preacher. As the preaching session drew to a close, with roles divided and ingredient lists drawn, Takenaka, the head of Myōkōji's women association, turned to Kolata saying, "It is our job to feed Amida Buddha and the men and women attending the gathering," and explained that there are women who chop beautifully, others with incomparable seasoning skills, and those useful in different ways such as washing vegetables, serving tea, and drying dishes. Since it was Kolata's first time helping the women deliver the meal, she was only allowed to tidy, wash the pots, and observe. Although her slicing and chopping skills never made it past aesthetic scrutiny, the second time she helped with the preparations, she was permitted to arrange the lunch boxes. ${ }^{10}$

Just as Aoyama explained earlier, women did the labor of planning, cooking, arranging, and presenting the food consumed by all. They possessed both knowledge about the symbolism of the meritorious and relational nature of Buddhist giving (Kolata 2019: 85-115; Langer 2019; Starling 2019: 63-80) and embodied knowledge applied through their micropractices of cutting, seasoning, and pairing foods. This expertise enabled them to attend to the aesthetics of food and ensure that the experience was shared and appreciated collectively and individually. It was the fujinkai women on cooking duties who enlivened the materiality of food and attended to the symbolic and sentimental value of their own and others' encounters with Buddhism. Hence, they created the boundedness of the environments where such encounters take place while enjoying what others might see as exclusion by stepping behind the scenes of more formal participation in Buddhist practice.

That day at Myōkōji, although the food prepared was consumed by all, there was a clear separation between those who were there as helpers and those who attended the service. Although divisions were visible along gendered lines, further divisions among women occurred that separated helpers from attendees.

10 Even so, one day when put to the test, one of the women said laughingly, "Not bad, but perhaps leave chopping to Ushiyama. Let's not make Amida cry today." 
Women on cooking duty occupied spaces where the labor took place, donned in working attire of aprons, headkerchiefs, and sleeve protectors. Having spent an entire morning in the kitchen, their clothes and hair soaked up sweat and the smell of cooking rice. They did not join the other members of the temple in consuming the meal they had just prepared. Those not directly involved in cooking and tasked with carefully arranging food in individual lunch boxes were collectively deemed to be presentable enough to serve tea, offer soup refills, and attend to the guest preacher. The cooks stayed in the kitchen sipping tea and tidying their working stations. Eventually they took their allocated lunch boxes home to be consumed together with their families. Women chose to maintain boundaries between hosts and guests to purposefully shape the affective experiences of Buddhist preaching sessions for themselves and others. This choice is tied to the nature of fujinkai membership that recognizes formal participation in the Buddhist service and the more quotidian staging of it as Buddhist practice.

Boundaries between and among women are important for them to articulate and understand their roles within the larger Buddhist community and their work as essential to the creation of Buddhist value and affinity. Sara Ahmed suggests that such borders are maintained through transgression or avoidance of transgression (2004: 87). In Ahmed's example, disgust is a reaction to things, beings, and instances that instill conflict, what she terms "border objects." The aesthetics and embodied knowledge and experience of food also have the capacity for discerning border objects. How food smells on the body, how it lingers on the tongue, how it evokes pleasure, discomfort, and disgust are part of the processes whereby women use their food literacy to erect, challenge, reinforce, and navigate borders of belonging. Women's bodies are therefore movable border objects, whose circulation allows for reshuffling of when and how boundaries are emplaced.

Hirata, a seventy-five-year-old member of Myōkōji's fujinkai, was often tasked with scrutinizing the food's seasoning and preparing the meal's soup. When Kolata asked why Hirata was not joining the attending members in eating, she explained that people participated in the event to enjoy the preaching and food in a relaxed atmosphere and felt that the cooking odors lingering on her body and clothes would have been a transgression:

Hirata: If I joined the others, someone would have to sit next to me. Rather than enjoy their meal, smell the soup, and savor the saltiness of a pickle, they would smell me.

Kolata: But you do not stink. You just smell of food. 
Hirata: Maybe not, but I have the smell of my morning labor on me. It would spoil the atmosphere. Today, I am here to work for Amida Buddha, to treat others. Next time, I will be treated. I will get to just sit and listen to the teachings. For now, this smell of food on me will remind me of the work I was able to do for the benefit of others and for the buddhas.

For Hirata, borders between those who served and those who feasted were clearly demarcated through the division of labor and the affective capacities of laboring with food. The smell of it oriented her and other members' sense of belonging within their Buddhist community of practitioners. It also dictated how that belonging was performed through food literacy. There is an awareness of the tension between the smell of the food filling up the dining room enjoyed during a communal meal and its lingering scent carried on people's clothes and bodies after laboring in the temple's kitchen.

Both constitute the aforementioned "border objects" with diverse emotional and material consequences for aligning individuals with communities. Hirata did not want to disrupt other's experience of the Buddhist feast, and also avoided the embarrassment she would face by entering the banquet room with her clothing and body marked by her morning labor and associated odors of sweat and cooking. The cooks and guests did not ultimately belong to two different communities but, out of consideration for both groups' aesthetic experiences of food, they remained distinct.

Women used their food literacy to cultivate connectivity through specific roles as either hosts or feasters thereby crafting affective clusters of belonging through food: those who cooked offered their labor while those who feasted received others' generosity and brought a monetary donation to the temple. The lines between and among Buddhist women are often blurred or invisible through their shared food literacy but the rotating nature of the roles they assume reveals the acknowledgment of how diverse Buddhist practices can be equally valued. Thus, the self-discipline they practice when they map out those boundaries is both constraining and liberating.

Food literacy, which enables recognition and enforcement of those boundaries, circulates among women as a currency that brings women into various, sometimes conflicting, Buddhist communities. Cultivating the proper taste for the proper preparation and consumption of the proper food can bring individuals closer into a group, while failure at producing or even understanding these can lead to disconnection, albeit temporary. For Hirata, exclusion from a given cluster at one time meant inclusion in another. Notably, those roles are not static among women. Food literacy thus constitutes a bounded, gendered currency that allows Hirata and other women in the fujinkai kitchen to trade 
places and interrelate to one another in their experiences of Buddhist practice through varied food processes and their assumed roles in traditional Buddhist temple communities such as Myōkōji. Value is effectively stored as women's knowledge of food and they can deploy it to foster connections and delineate the boundaries around which such connections are established.

ILAB reveals a similar kind of division between those who prepare food and those who consume it but based around a different border object, illuminating how economic contexts also shape the aesthetics of religious belonging." Gillson attended the March 2017 Buddhist Cultural Exchange Circle held in Yokohama, a port town near Tokyo. Housed at the main temple of the president (Nakano Michiko) and vice president (Nakano Jane) of the organization who are mother- and daughter-in-law and leaders of a lay-focused branch of the Tendai Buddhist sect, this meeting concluded with a feast. It also roughly coincided with Girls' Day, the Japanese holiday celebrating girls, which includes the consumption of particular foods. In the presence of beautiful and ornate dolls dressed like nobles from the Heian period (794-1185), a waitress dressed in a crisp professional black and white outfit served Gillson and other guests amazake, a sweet, thick rice-alcohol with suspended white solids, often enjoyed warm.

After amazake refreshments and admiring the dolls, Michiko invited everyone to enjoy the food and the room split largely into chaos as additional servers carried platters laden with food to a large serving table. This included a gigantic bowl of slightly vinegared rice covered in omelet strips, fish eggs, and green onions. It was placed next to a platter of small vegetable-stuffed steamed dumplings and another platter of Chinese peach-shaped buns filled with red bean paste. As Gillson took a seat, an ILAB member brought over a plate piled with sushi and one each of the buns and dumplings, alongside a covered bowl filled with clear soup speckled with tiny clam shells. All the food was both fragrant and delicious and many women clearly enjoyed the feast. Although servers and other ILAB members continually offered them food, neither Michiko nor Jane ate. Instead, they circled the room as hosts, conversing with participants, calling over servers if necessary, and generally making sure guests enjoyed themselves. Many women commented on the deliciousness of the food and how it complemented the beautiful dolls in the sophisticated, classically furnished tearoom, the Buddhist artwork hanging

11 ILAB, as the name implies, aims for an international reach. Nevertheless, the group is heavily weighted toward Japanese women, often with international connections such as diplomats' wives, with most conversations carried out in Japanese. For a detailed examination, see Gillson 2018: 219-270. 
on the walls, and the sunny yet chilly March morning weather. Although Jane explained apologetically to Gillson that this was a cultural rather than explicitly Buddhist event, many women praised the setting, food, and company that helped them appreciate Buddhism and feel Buddhist.

Paired with Myōkōji, ILAB clearly presents a different aesthetic context, wherein women do not physically perform any of the cooking labor that goes into the feasts. Michiko welcomed and invited Gillson and other guests to eat the feast she coordinated. Rather than personally preparing the food, she shifted that labor to (presumably) an in-house chef. For participants, this does not make the food any less hers or any less valuable. Instead, it exemplifies the expectations of a woman of her high social class where food must be absolutely perfect and emulate the elegance of the surroundings. Michiko and Jane, as hosts, felt they would be judged by the guests and Buddhist deities in their temple on the feast's quality.

Importantly, Michiko did not serve anybody directly but instead hired waiters and waitresses. Even when ILAB women took over serving, it was not Michiko herself but two other ILAB members who decided to serve the crowded and bustling room. Michiko focused her labor in other ways: explaining the Buddhist artwork on the walls, guiding people through the tearoom, and moving among the crowd to make sure guests were having a wholesome and, as she noted, "restorative" experience. The ILAB hosts did not eat the food they presented, just as the women who labored to prepare food at Myōkōji did not eat with their guests. In both vignettes, women understood the importance of knowledge and practices concerning food as a gendered currency, drawing on shared aesthetics to negotiate their own and others' senses of belonging.

The communal experience of eating food brings women both physically and emotionally together in accordance with their temporary roles. Even though Jane apologized for the "cultural" focus of the gathering, other ILAB participants' reflections on how perfectly the setting, people, and food cultivated, in Michiko's words, their "Buddhist feeling" indicate that they perceived this, at least in part, to be a religious experience. For ILAB and Myōkōji members equally, carefully crafted food-centered encounters with Buddhism aesthetically brought them into Buddhist networks. Both instances therefore expose boundaries of belonging facilitated by affective and material dimensions. From kitchens to feasts, food literacy circulates among women to both construct and make visible the borders between and among women even as those borders are somewhat permeable and fluid.

These two examples illuminate how food literacy becomes a gendered currency that makes visible the border objects that delineate belonging. The borders are drawn along the divisions between guests and hosts (see also in this 
issue, Brox 2021; Caple 2021) with Hirata's and Michiko's bodies effectively constituting border objects. For Hirata, the smell of her work aesthetically defines how she chose to experience Buddhism and deemed it inappropriate to enter the dining space in her sweat- and cooking-scented clothing. She refrains from participating at that particular feast to preserve what she felt was the appropriate aesthetic context for her carefully crafted food. Similarly, Michiko resists the transgression between hosts and guests at this Buddhist gathering by focusing on hosting, implicitly embodying the bodhisattva virtue of generosity toward others. She attempts to embody Buddhist values that are in conversation with her social status and performative distinctions implied within it. As such, she strives to reconcile competing and coexisting values of her socioreligious identities. Women who share understandings of the complex dynamics surrounding food in turn share understandings and valuations of food and hosting as aesthetic practices which help bring them together in mutual appreciation of the labor that goes into its production and presentation. It circulates, quite literally, around the women who produce, consume, and appreciate it.

\section{Negotiating Food Literacy through Self-Discipline}

Aki, previously introduced as the wife of Myōkōji's head priest, was often Kolata's guide into the Buddhist world of food. Kolata regularly assisted her during temple events in preparing meals for parishioners, when Aki preferred to cook in her family kitchen to mitigate against their potential scrutiny. One day in May 2017, Kolata was summoned hurriedly to her kitchen to help. "It's shōjin ryōri today," Kolata heard Aki say when entering the kitchen, "it is Shinran's [the sect's founder] birthday, so all has to taste just right and look beautiful today. No mistakes." Aki's swift but measured movements and calm concentration painted on her face and reflected in her regimented bodily motions indicated that everything was under control in the kitchen, but she remained tense. As she carefully scrutinized the flavors, textures, and color pairings of foods, Aki explained to Kolata that her cookery was going to be enjoyed and judged by her fellow lay Buddhist women. She anticipated that women attending the service would compliment her cooking skills, but would watch their faces attentively to measure the truthfulness of their exclamations and assertions.

As a custodian of the temple, Aki was expected to possess food literacy superior to other women. She was to lead other Buddhist women in her community by example. Her job was not only to showcase her excellent hosting 
skills, but also to convey the Buddhist meaning of the food she offered. Namely, it was an educational tool meant to inspire the virtues of simplicity, generosity, and frugality in those consuming the food. Shöjin, Aki clarified a few days prior when designing that day's menu, is a very simple form of cooking. It literally means concentration, diligence, and devotion, and thus, committing to and practicing a shöjin diet is one way to express people's zeal in their quests for enlightenment. Aki understood that shöjin ryōri meant performing and experiencing Buddhism through food as an important part of Japanese Buddhist practice she shared with others. Taking stock of vegetables and grains in her temple kitchen donated by Myōkōji's supporters, she explained that this kind of food requires little seasoning as most flavor should come from the quality of the ingredients and the cook's skill to preserve it, rendering important seasonal produce and waste minimization. Thus, Aki was expected to display food and economic literacy when managing temple affairs. How, where, of what quality, and at what expense the produce was acquired should be noticeable and appreciated when consumed, and when Myōkōji's budgets are reviewed at the next temple board meeting.

That morning, as Aki folded rice and azuki beans, her head kept tilting as if assessing the quality of the rice from different directions. Raising her head, she asked, "How is it looking?" The rice was steaming, shiny with sticky glutinousness and tinted red with burgundy skins of azuki beans. To Kolata's amateur eye, it looked delicious. Aki, however, was assessing the aesthetic ratio of the whiteness of rice to the redness of azuki beans that would also influence its taste. Kolata was tasked with arranging the crockery on individual lacquer trays in accordance with a diagram drafted in Aki's hand, while Aki sliced the pickled vegetables prepared a few days earlier. The noise from the speaker installed in the kitchen made it clear that the morning service was drawing to a close. Kolata moved swiftly, plating the rice, tofu dishes, and pickles, each on its designated dish. Meanwhile, Aki watched the aesthetic outcomes and, every so often, grabbed a pair of chopsticks to correct the arrangement or issued instructions on the shape and quantity of rice served. Owing to the simplicity of shōjin ryōri, Aki felt there was nowhere to hide and, as she explained, it was her responsibility to ensure the meal served today pleased and affected the senses of parishioners, Amida Buddha, and Shinran, whose birthday was celebrated that day.

She faced pressure to prove that she possessed the required food literacy to make the most of the ingredients donated by parishioners and reflect Buddhist values and womanly virtues of right morality, behavior, and labor reflected in the food she prepared for her community. The feminine ideal of Buddhist 
women as nurturing the next generation of Buddhist practitioners has prevailed in contemporary Japan (Starling 2013), especially in rural communities. Therefore, the normative gendered division of labor, that assigns women to the domestic sphere and men to working outside the home, is reinforced in many temple households (Starling 2019: 37-43). Wives should guide and inspire female lay members in their dedication to nurturing the domestic sphere of their Buddhist communities. Aki was a nurse in her previous professional life who married into a Buddhist temple family. Contrary to many women who grew up at a temple, she was an outsider who lacked years of socialization into a temple wife's role and its associated culinary skills. When she arrived at Myōkōji over two decades ago, she enrolled in a cooking course for temple wives in order to understand the flavors she was expected to replicate and develop sensitivity to Buddhist food aesthetics. Her ability to deploy her food literacy to inspire Buddhist morality and nurture a relationship of closeness with Shinran and, by extension, her temple was paramount.

Once all the food was served and parishioners left the temple, Aki poured tea, sighed with relief, and said with a smile, "After all these years, I still feel like an amateur. You see, my mother-in-law, as a temple wife, was in a class of her own." This was not the first time Kolata heard her praise other women. Whenever Aki and Kolata visited other temples for social calls, Aki would react in one of two ways. Either she would whisper approving comments on the cookery, choices of crockery, and even minute details of presentation and attire, or she would explain that a fellow temple wife shared her own background or was similarly more relaxed about the food prepared and served at her temple. Sometimes, she formalized her bodily movements and made mental notes on presentation styles and recipes for food combinations she then recreated. Other times, she relaxed and explained, "The food is always delicious here, but they just cobble it up together, a bit like I do." Aki felt a far greater affinity with the latter but was expected to forge connections with both. When Aki first met Myōkōji's head priest, her future husband, he possessed excellent cooking skills and looked after the domestic sphere. It was after their move to Myōkōji when Aki understood the necessity of her food literacy as a tool for connecting with her new community. As an outsider, in religious and social terms, Aki negotiated her own Buddhist practice through self-discipline in the food she prepared at her temple. Likewise, other Buddhist women often used food as aspirational and emotional benchmarks for curating their individual Buddhist identities, their individual capacity for embodying the appropriate socioreligious values, and the affective dimensions that their individual practice may possess for effecting Buddhist senses of belonging in others. 
Food literacy thus can be used to negotiate around border objects, constructing and making visible borders between women based upon the values underpinning their individual and collective Buddhist identities. When differing forms of food literacy interact, borders are erected but bring women into differing spheres of belonging and processes of negotiation can fail. Aki, despite her extensive food literacy cultivated through continuous self-disciplining in the service of Buddhist community-building, nonetheless, remains partially emotionally alienated from that very community. This, however, does not mean that belonging fails. Rather, connections are established along different lines of belonging such as urban/rural divides, sectarian affiliations, and national Buddhist identities. Notably, these connections are also oriented toward different objects of belonging including concrete physical symbols or imagined community networks.

Gillson's encounter with a Taiwanese Buddhist nun at the March 2017 Girls' Day themed ILAB meeting described earlier demonstrates precisely this. Recall the festive atmosphere of women moving about the room to admire artwork, discuss Buddhism, and eat delicious food. As Gillson observed the festivities at one of the long folding tables, a nun wearing the light gray robes of a Taiwanese monastic novice seated herself opposite. She introduced herself as Novice Lu, who was invited by her teacher to attend the meeting. A few people noticed that Lu did not have food and eagerly offered some, resulting in her increasingly obvious discomfort. A woman excitedly asked: "It must be your first time [to try the food], right?" but Lu responded, "I'm vegetarian only, unfortunately" which caused the woman to apologize and retreat. The husband of an ILAB board member, Ôno Yuki, overheard and commented that it would be terrible to not be able to eat the feast because what if she liked it when she tried it. Novice Lu responded, "Ah, I probably wouldn't like it that much. It's beneficial for the stomach [to abstain]." He responded surprised, "Is it bad for you?" and she retorted, "I'm fine the way I am." She resisted until he finally retreated.

Jane, the co-host, then came to the table to talk. An ILAB woman handed her a plate piled with sushi but Jane left to attend to other guests, abandoning the untouched plate of raw fish. Another woman commented on the deliciousness of the soup, saw the abandoned plate of sushi, and offered it to Novice Lu who responded a little more ardently, "Thank you but I'm fine. Seriously, I'm fine!" To which the woman responded, "You're so shöjin!", using the same term discussed by Aki but here referring to a person rigidly committed to a vegetarian monastic diet as an important way to express her avidity in pursuing enlightenment. The nun's attitude seemed a little overzealous to the woman who jokingly called her shöjin. After this pointed encounter, it seemed that she would finally be left alone. As a Taiwanese Buddhist nun, she saw dedication 
to the vegetarian lifestyle as essential for devout Buddhists and in exasperation said to Gillson, "When you do not eat meat for a long time, you stop craving it. Vegetables come to taste sweet and delicious." She pointed disdainfully at the plate of leftover sushi and commented on its "stench." She left the meeting shortly afterward with a slightly perturbed look on her face.

The way the majority of ILAB participants experienced the banquet, delighting in meat dishes and alcohol permitted in the Japanese Buddhist diet, made clear their shared sense of religious belonging. ${ }^{12}$ In contrast to Jane, who as a host was allowed but refrained from eating, Novice Lu's rejection of the food illustrates how the same repast can be construed very differently when drawing on different understandings of food in the aesthetic creation of Buddhist selves. Her body, specifically her mouth, became a border object, "a gateway through which [she] guards and protects the self from the outside" (Harbottle 1997: 178). Determining what and how food is consumed enabled both sets of participants to realize, self-discipline, and negotiate their religious and cultural values through individual and collective practices. When the ILAB hosts presented a meal that appealed to a particular sense of Japanese Buddhist aesthetics and tastes that allows meat and alcohol, they made visible boundaries between their understanding of Buddhism and that of Novice Lu who, similar to Chinese vegetarian nuns (Cho 2015: 209), appeared to equate the correct form of Buddhist practice with certain dietary restrictions, nutritional knowledge, and eating techniques. What was missing was a shared sense of empathy. Food literacy can become a site of failure to craft religious belonging through aesthetics if the intended audience fails to emotionally connect with them (see Williams-Oerberg 2021 [this issue]).

The areas of interactions, the movements of women in and out of this particular path of doing Buddhism, reinforce the boundaries and the belonging of women to different Buddhist groups (see Brox 2021 [this issue]). Of note here are not the bodily enactments of dietary self-discipline, but the tensions between borders demarcated according to expectations of sophistication and simplicity of two dietary ideals: high-class Japanese Buddhist women and an ordained Taiwanese Buddhist novice. How Novice Lu and ILAB members deploy their gendered currency of food literacy corresponds with their individual interpretation of Buddhist values. The Taiwanese nun's own knowledge

12 Meat eating remains a contentious aspect in Japanese Buddhist food history. Although shōjin ryōri remains an ideal of Buddhist food, most Buddhist religious professionals in Japan regularly consume meat and adhere to vegetarianism only on special days intended as an expression of focused Buddhist piety; see: Jaffe 2001; Ćwiertka 2006: 12. Also, see Ambros 2019 on consuming animals with gratitude as a form of Buddhist practice. 
concerning food in the Buddhist context is used to claim a higher moral ground in relation to ILAB women who, in her eyes, violate Buddhist vegetarianism. Their lack of desire for dialogue pulls them into different spheres of Buddhist belonging, based on differing communal interpretations of Buddhism. The woman who called Novice Lu "such a shöjin" dressed the Buddhist ideal of vegetarian food as an excessive and cumbersome adherence to certain Buddhist virtues, while Novice Lu's senses were violated by the "stench" of sushi appreciated by others at the feast, forcing her to leave.

The practices of boundary making involving food literacy in Buddhist contexts are often translated into various dimensions of normative accountability: what does it mean to possess a shared understanding of socioreligious values, emotional clues, and sensorial memories that are designed to bring people together and what happens when they diverge. The negotiation processes involved reveal the disciplining function of food literacy and the techniques used to articulate its parameters. How food tastes, looks, and smells can aid self-evaluation of women's own food literacy and, by extension, their Buddhist selves. Although the rules relating to foodways and women's engagement and labor in and through food have been produced in the wider social, political, and religious contexts, Aki and Novice Lu are the ones who, in the intimacy of their self-disciplining, use their food literacy to cultivate belonging to different Buddhist networks. Attending carefully to the micro-level practices realized through food literacy thus reveals how the affective dimensions of food create aesthetic formations of Buddhist belonging that are local, subjective, and intentional. Sometimes women's narratives and practices concerning food literacy are aspirational insofar as they highlight deficiencies in knowledge and skill that ought to be acknowledged and addressed. Women in our ethnographies used their food literacy as a vehicle for crafting belonging, negotiating their senses of togetherness within varying Buddhist contexts. Gendered currency thus serves to illuminate how those connections are forged or how they sometimes fail to be established.

What women know about food in the Buddhist context and how they acquire and employ that knowledge reveals the complexities of women's belonging and affects the ways the broader community comes together on an aesthetic level. How Buddhism smells, looks, tastes, and feels is encoded in the ratio of rice to azuki beans, in the gelatinous form of mountain potato soup, in the carefully considered balance between sophistication and simplicity of 
crockery, and in the smell of white miso soup mixed with the sweat of kitchen labor lingering on the cook's headkerchief. Food-related labor in the Buddhist context is not just domestic labor, it is meritorious. It represents small projects whereby women forge connections and experience the values and meanings of Buddhist practice. Through food literacy, women teach, learn, and practice the meanings and ways of doing Buddhism. They perform and narrate how food in Buddhist settings feels and the affective traces it etches onto a person's emotional, social, and material body. The circulating, boundary-making, disciplining, and pedagogical nature of food literacy we have shown illuminates the mundane complexities of how food literacy as a gendered currency flows from person to person, establishing connections and realizing, successfully or otherwise, Buddhist women's senses of belonging.

Gendered currency therefore constitutes not only a symbolic value but one that is materialized, mobilized (and mobile), and relational. Women's active engagement in foodways reveals the boundaries and tensions in engendering Buddhist value systems. Such boundaries help women navigate and recognize where and how these value negotiations should take place and the importance of their food literacy as a currency enabling these negotiations. At times, such boundary negotiation fails, but rather than a failure of belonging, it shows how differing interpretations of Buddhist virtues can lead to differing senses of religious belonging. As such, food literacy constitutes a fluid and fluctuating form of gendered currency, which when deployed does not lose value. Instead, if circulated at an individual level, it gains traction and can create belonging. The prerequisite for it to drive belonging at a collective level, however, is a shared communal interpretation of Buddhist virtues and how those virtues are practiced. Food literacy and the aesthetic experiences it generates can illuminate value encoded in micropractices involving food that drives religious belonging and the dynamic and complex negotiation processes employed in the creation of women's Buddhist selves.

\section{Acknowledgments}

We gratefully acknowledge the financial support provided by the AH RC's North West Doctoral Consortium Doctoral Training Partnership and ESRC's North West Social Science Doctoral Training Partnership for Kolata's fieldwork and by the University of Iowa and the US-Japan Fulbright Commission for Gillson's research. We are indebted to the many wonderful women who entrusted us with their stories and experiences of Buddhism. We also thank the fellow authors in this issue for comments on the early drafts of this article, as well as 
Erica Baffelli, Levi McLaughlin, Vlad Schüler Costa, and Dawn Llewellyn for their insightful comments on various iterations of this article. Finally, we are grateful to the reviewers and journal editors, Laura Feldt and Ülo Valk, for the careful reading of our work.

\section{References}

Ahmed, Sara. 2004. "Affective Economies." Social Text 22(2): 117-139. DoI:10.1215/ 01642472-22-2_79-117.

Ahmed, Sara. 2015. The Cultural Politics of Emotion. 2nd ed. Durham, NC: Duke University Press.

Ambros, Barbara R. 2019. "Partaking in Life: Buddhism, Meat-Eating, and Sacrificial Discourses of Gratitude in Contemporary Japan.” Religions 10(4): 279-300. DoI: 10.339o/rel10040279.

Arnold, Philip P. 200o. "Eating and Giving Food:The Material Necessity of Interpretation in Thai Buddhism." Journal of Ritual Studies 14(1): 6-22.

Banerji, Chitrita. 2006. Feeding the Gods: Memories of Food and Culture in Bengal. London: Seagull Books.

Befu, Harumi. 1968. "Gift-Giving in a Modernizing Japan." Monumenta Nipponica 23 (3-4): 445-456. DoI:10.2307/2383499.

Bender, Courtney, and Ann Taves. 2012. What Matters?: Ethnographies of Value in a Not So Secular Age. New York: Columbia University Press.

Brox, Trine. 2021. "The Aesthetics of In/Authenticity: Buddhism, Commodification, and Ethnoreligious Belonging in a Sino-Tibetan Contact Zone." Numen 68(5-6): 540-566. DoI:10.1163/15685276-12341639.

Caple,Jane. 2015. "Faith, Generosity, Knowledge and the Buddhist Gift: Moral Discourses on Chinese Patronage of Tibetan Buddhist Monasteries." Religion Compass 9(11): 462-482. DoI:10.1111/rec3.12181.

Caple, Jane. 2021. "Feeling Apart: Relations of Belonging in Tibetan Buddhist LayMonastic Communities." Numen 68(5-6): 463-487. DoI:10.1163/15685276-12341636.

Cho, Yasmin. 2015. "Politics of Tranquility: Religious Mobilities and Material Engagements of Tibetan Buddhist Nuns in Post-Mao China." PhD dissertation, Duke University.

Covell, Stephen G. 2005. Japanese Temple Buddhism: Worldliness in a Religion of Renunciation. (Topics in Contemporary Buddhism). Honolulu: University of Hawai'i Press.

Ćwiertka, Katarzyna Joanna. 20o6. Modern Japanese Cuisine: Food, Power and National Identity. London: Reaktion Books. 
Gillson, Gwendolyn. 2018. "The Buddhist Ties of Japanese Women: Crafting Relationships between Nuns and Laywomen." PhD dissertation, University of Iowa. DoI:10.17077/etd.ec4j1shv.

Graeber, David. 2001. Toward an Anthropological Theory of Value: The False Coin of Our Own Dreams. New York: Palgrave. DoI:10.1057/9780312299064.

Gross, Rachel B. 2019. "Table Talk: American Jewish Foodways and the Study of Religion." Religion Compass 13(4): 1-10. DoI:10.1111/rec3.12297.

Gross, Rachel B. 2021. Beyond the Synagogue:Jewish Nostalgia as Religious Practice. New York: New York University Press.

Gunson, Jeremy J. 2019. "From Client to Comrade: Alternative Currency and Market Relations in Mexico." PhD dissertation, The University of Manchester.

Harbottle, Lynn. 1997. "Taste and Embodiment: The Food Preferences of Iranians in Britain." In Helen Macbeth (ed.), Food Preferences and Taste: Continuity and Change, New York: Berghahn Books, 175-186.

Hart, Keith. 200o. The Memory Bank: Money in an Unequal World. London: Profile.

Holtzman, Jon D. 20o6. "Food and Memory." Annual Review of Anthropology 35(1): 361378. Dor:10.1146/annurev.anthro.35.081705.123220.

Jaffe, Richard. 2001. Neither Monk Nor Layman: Clerical Marriage in Modern Japanese Buddhism. Princeton, NJ: Princeton University Press.

Kawahashi, Noriko. 2003. "Feminist Buddhism as Praxis: Women in Traditional Buddhism." Japanese Journal of Religious Studies 30(3-4): 291-313.

Kolata, Paulina K. 2019. "Japanese Buddhist Temple Communities in Transition: Doing Belonging in Troubled Times.” PhD dissertation, The University of Manchester.

Langer, Rita. 2019. "The Transformative Power of Food:The 'Milk Mothers' in Sri Lankan Buddhism." Material Religion 15(5):529-552. DoI:10.1080/17432200.2019.1670380.

Li, Yuhang. 2020. Becoming Guanyin: Artistic Devotion of Buddhist Women in Late Imperial China. New York: Columbia University Press.

Long, Lucy M. 2004. Culinary Tourism. Lexington: University Press of Kentucky.

Lowe, Bryan. 2017. Ritualized Writing: Buddhist Practice and Scriptural Cultures in Ancient Japan. Honolulu: University of Hawai'i Press.

McDowell Aoki, Deborah. 200o. "Widow's Rites in Japan: An Interpretive Study of Women's Participation in Memorial Rituals and the Transformation of Family Practices." U.S.-Japan Women's Journal 18(English Supplement): 84-106.

Meeker, Lauren. 2019. "Being Witnessed Saving Others: Moral Personhood in Women's Popular Buddhist Practice in Rural Northern Vietnam.” The Journal of Asian Studies 78(2): 309-328. DoI:10.1017/Soo2191181900oo68.

Meyer, Birgit. 2009. "From Imagined Communities to Aesthetic Formations: Religious Mediations, Sensational Forms, and Styles of Binding." In Birgit Meyer (ed.), Aesthetic Formations: Media, Religion, and the Senses, New York: Palgrave Macmillan, 1-28. 
Munn, Nancy. 1986. The Fame of Gawa: A Symbolic Study of Value Transformation in a Massim (Papua New Guinea) Society. Cambridge: Cambridge University Press.

Onions, Charles T. (ed.). 1966. The Oxford Dictionary of English Etymology. Oxford: Oxford University Press.

Pérez, Elizabeth. 2016. Religion in the Kitchen: Cooking, Talking, and the Making of Black Atlantic Traditions. New York: New York University Press.

Salgado, Nirmala S. 2013. Buddhist Nuns and Gendered Practice: In Search of the Female Renunciant. New York: Oxford University Press.

Sihlè, Nicolas. 2015. "The Comparative Anthropology of the Buddhist Gift (and Other Transfers)." Religion Compass 9(11): 352-385. DOI:10.1111/rec3.12185.

Starling, Jessica. 2013. "Neither Nun nor Laywoman:The Good Wives and Wise Mothers of Jōdo Shinshū Temples." Japanese Journal of Religious Studies 4O(2): 277-301.

Starling, Jessica. 2019. Guardians of the Buddha's Home: Domestic Religion in Contemporary Jōdo Shinshū. Honolulu: University of Hawai'i Press.

Trzebiatowska, Marta, and Steve Bruce. 2012. Why Are Women More Religious Than Men? Oxford: Oxford University Press.

Williams, Duncan Ryūken. 2005. The Other Side of Zen: A Social History of Sōtō Zen. Princeton, NJ: Princeton University Press.

Williams-Oerberg, Elizabeth. 2021. "Buddhist Ritual as 'Connectionwork': Aesthetics and Technologies of Mediating Religious Belonging." Numen 68(5-6): 488-512. DOI:10.1163/15685276-12341637.

Zeller, Benjamin. 2017. "Religion as Embodied Taste: Using Food to Rethink Religion." Body and Religion 1(1): 10-30. DOI:10.1558/bar.32834. 